\title{
THE EVOLUTION OF THE EAST ASIAN CURRENCY BASKETS - STILL UNDISCLOSED AND CHANGING
}

\author{
GUNTHER SCHNABL
}

CESIFO WORKING PAPER NO. 1873

CATEgory 6: Monetary Policy and InTERnational Finance

DECEMBER 2006

An electronic version of the paper may be downloaded

- from the SSRN website:

- from the RePEc website:

www.SSRN.com

- from the CESifo website:

www.RePEc.org

www.CESifo-group.de 


\title{
THE EVOLUTION OF THE EAST ASIAN CURRENCY BASKETS - STILL UNDISCLOSED AND CHANGING
}

\begin{abstract}
Both before and after the Asian crisis, the dollar has been the dominant anchor and reserve currency in East Asia. Due to underdeveloped capital markets and the limited international role of their domestic currencies, the East Asian countries (except Japan) are likely to continue to stabilize exchange rates and to accumulate international reserves. Yet expectations of further dollar depreciation may trigger a re-orientation of exchange rate policies based on basket strategies. Rolling econometric estimations of the basket structures in East Asia suggest growing weights for the Japanese yen in most East Asian currency baskets. The role of the euro as a reserve currency in East Asia remains uncertain.
\end{abstract}

JEL Code: F31, G15, E58.

Keywords: East Asia, currency basket, exchange rate policies, international role of the euro.

\author{
Gunther Schnabl \\ Leipzig University \\ Marschnerstr. 31 \\ 04109 Leipzig \\ Germany \\ schnabl@wifa.uni-leipzig.de
}

November 20, 2006

I thank Adrian Höhl, Constanze Lamprecht, Axel Löffler, and Ulrike Mühler for excellent research assistance. 


\section{More Exchange Rate Flexibility in East Asia?}

Before the 1997/98 Asian crisis, the East Asian countries China, Hong Kong, Indonesia, Korea, Malaysia, the Philippines, Singapore, Taiwan, and Thailand pursued a common exchange rate peg to the US dollar. This (informal) East Asian dollar standard (McKinnon and Schnabl 2004a) was beneficial for growth in the region for several reasons. First, it ensured macroeconomic stability by bringing the domestic rates of inflation close to the US level. Second, the joint peg to the dollar provided low transaction costs not only for trade with the US but also for intraregional trade flows, which make up about $50 \%$ of overall East Asian trade. Third, exchange rate stability provided low transaction costs for short-term and long-term international capital flows.

After the onset of the East Asian crisis, the East Asian dollar standard fell apart. While China, Hong Kong, Singapore, and Taiwan kept their exchange rates stable against the dollar, the currencies of the crisis countries Indonesia, Korea, Malaysia, the Philippines, and Thailand depreciated. The post-crisis policy recommendations for the exchange regimes in East Asia have been of diverse natures. Associating exchange rate stability against the dollar with overly low risk premia on volatile capital inflows, the IMF recommended (more) exchange rate flexibility (Fischer 2001). In contrast, McKinnon and Schnabl (2004a, 2004b) argue that exchange rate stabilization per se is not a reason for overinvestment and that even post-crisis, due to the high degree of dollarization of international transactions in the region exchange rate stabilization against the dollar is fully rational.

A third strand of literature has proposed maintaining exchange rate stability in the region, but pegging to more than one anchor currency. According to Williamson (2000, 2005), currency basket arrangements would be beneficial for the East Asian countries as they stabilize the nominal effective exchange rates. To maintain intra-regional exchange rate stability, Ogawa and Ito (2002) have proposed to coordinate the currency baskets in the region. Kawai (2006) argues that such coordinated currency baskets based on dollar, yen and euro can be a first step on the path towards an Asian monetary union.

While post-crisis East Asian exchange rate volatility against the dollar by and large declined (close) to the pre-crisis level, since the year 2005 exchange rate volatility against the dollar has increased. This may be due to either rising exchange rate flexibility or due to higher exchange rate stability against the yen, the euro, (or other currencies). 


\section{The Rationale for Exchange Rate Stabilization in East Asia}

Despite policy recommendations to pursue more exchange rate flexibility, fully flexible exchange rates such as between the dollar and the euro are unlikely in East Asia. This is because stable exchange rates in East Asia have proved to be beneficial for international trade, macroeconomic stability, and international capital flows in the region.

\section{International Trade}

Building upon Ricardo, the welfare gains originating in the international partition of labour are widely acknowledged. The policy implication is to remove exchange rate volatility to foster international trade and welfare. As in East Asia the growth performance has been strongly based on international and intra-regional trade, exchange rate stability has played a prominent role for economic policy making.

The impact of exchange rate volatility on trade has both a micro- and macroeconomic dimension. From a microeconomic perspective (high frequency) exchange rate volatility - for instance measured as day-to-day or week-to-week exchange rate fluctuations - is associated with higher costs for international goods and capital transactions because uncertainty is high and hedging foreign exchange risk is costly. Indirectly, fixed exchange rates enhance international price transparency as consumers can compare prices in different countries more easily. If exchange rate volatility is reduced or eliminated, international goods arbitrage enhances efficiency, productivity and welfare.

These microeconomic benefits of exchange rate stabilization have been, for instance, an important motivation of the European (monetary) integration process (European Commission 1990) which can be seen as a role model for East Asian monetary integration (Kawai 2006). In East Asia, before and after the Asian crisis, the East Asian countries strongly controlled day-today exchange rate fluctuations as shown in Figure 1. Compared to the freely floating euro/dollar rate the daily fluctuations of the East Asian currencies against the dollar were kept - except for the Asian crisis period - at a significantly lower levels than the benchmark freely floating euro against the dollar. 
Figure 1: Exchange Rate Volatility Against the US Dollar, 1990:01-2006:08 (Daily)

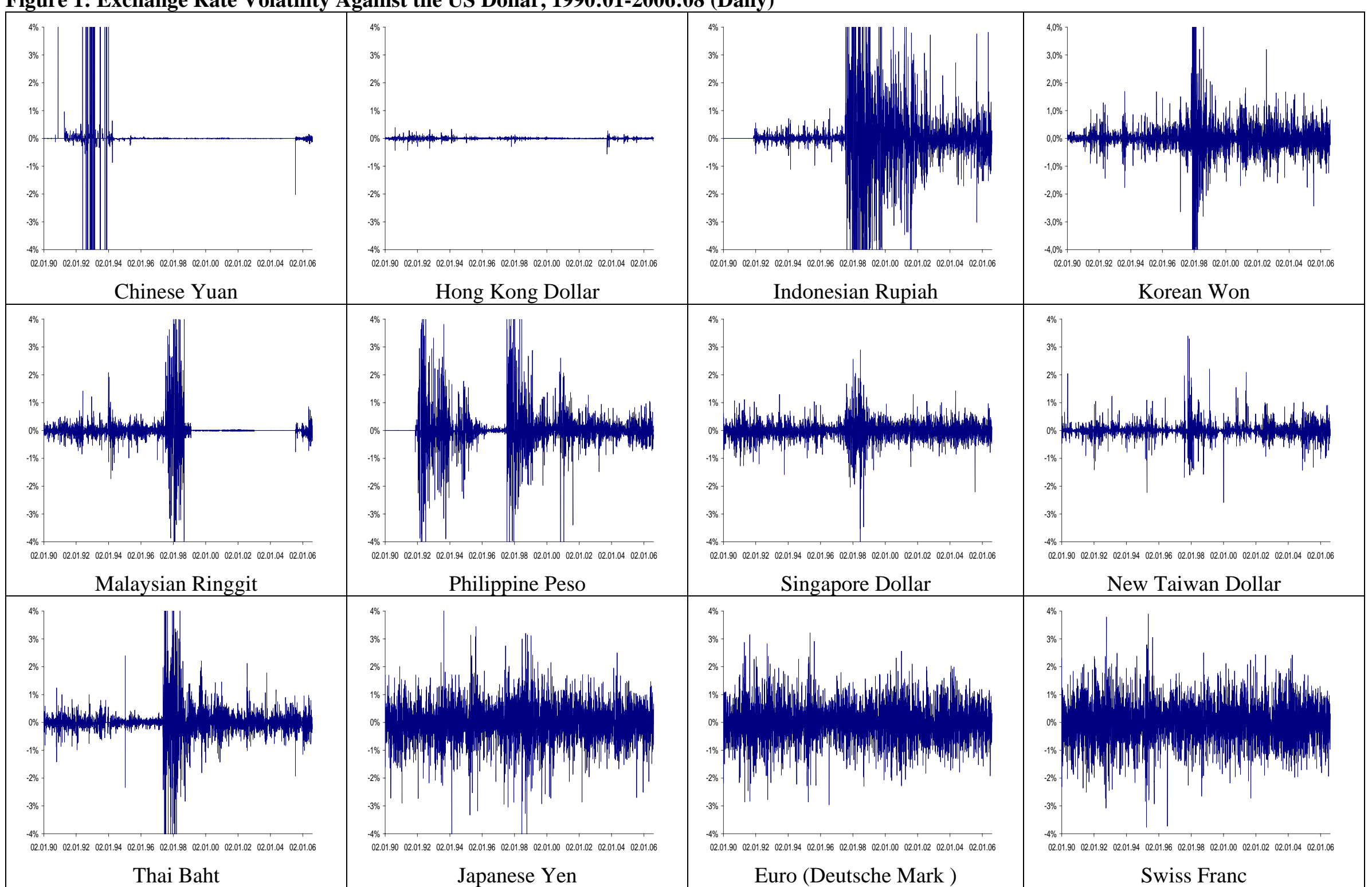

Source: Bloomberg. Volatility is measured in daily percentage changes against the dollar. 
The macroeconomic dimension arises from the fact that long-term exchange rate fluctuations for instance measured as monthly or yearly changes of the exchange rate level - affect the competitiveness of domestic export and import competing industries. In small open economies the growth performance can be strongly influenced by long-term fluctuations of the exchange rate level. Even large, comparatively closed economies such Japan have proved to be sensitive to large exchange rate swings, in particular in the case of appreciation. For instance, McKinnon and Ohno (1997) show for Japan that since the early 1970s when the yen became flexible against the dollar growth has been strongly slowed down by the appreciation of the Japanese currency.

\section{Macroeconomic Stability}

While exchange rate fluctuations can influence the macroeconomic stability of in open economy significantly through the trade channel, there are also direct linkages such as via monetary policy making. As put forward by McKinnon (1963) pegged exchange rates are an important tool for macroeconomic stabilization in small open economies. Assuming that for small economies the international price level is given and traded goods make up a high share of the domestically consumed goods, exchange rate volatility translates into domestic price level fluctuations. The welfare effect of stable exchange rates originates in macroeconomic stability which provides a favourable environment for investment and consumption.

Furthermore, emerging markets and developing countries mostly do not have a history of central bank independence and macroeconomic stability. As monetary policy is often a tool to finance government expenditure, inflation and depreciation are the result. In this context pegged exchange rates provide an important tool to contain inflation tax via both a commitment towards exchange rate stability and a disciplining effect on monetary growth (Crocket and Goldstein, 1976).

As stressed by McKinnon and Schnabl (2004a) before the Asian crisis the East Asian countries pinned down their price levels close to the level of the US by pegging their exchange rates commonly to the US dollar. These tight dollar pegs are shown in Figure 2. International and intra-regional goods market arbitrage further enhanced the low inflation environment which can be seen as a crucial determinant of the (pre-crisis) East Asian economic miracle. 
Figure 2: East Asian Exchange Rates against the Dollar, 1990:01-2006:08

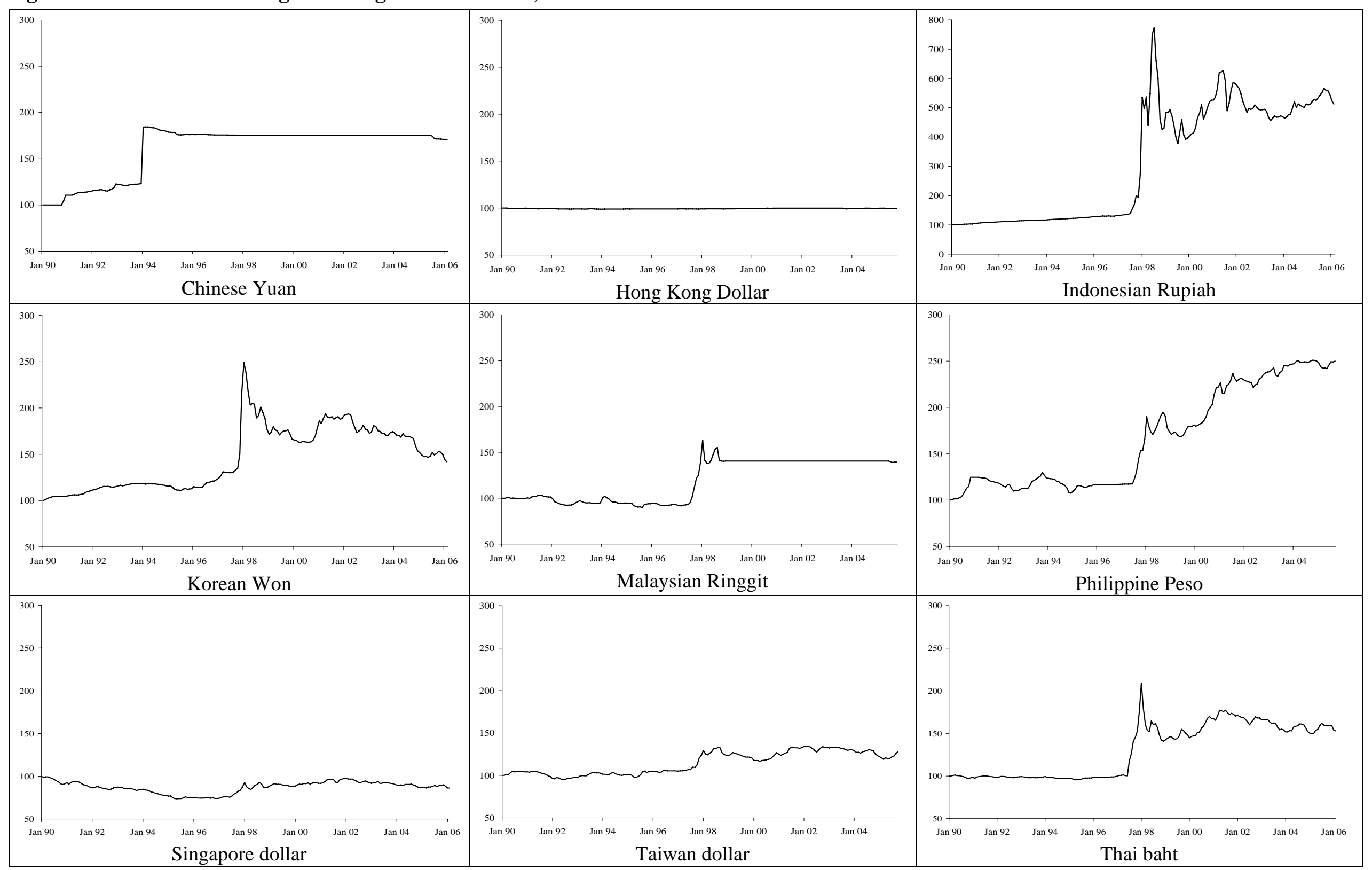

Source: IMF: IFS, Central Bank of China. Index 1990.01=100. Note different scale for Indonesia. 


\section{Financial Markets}

After the Asian crisis, financial markets have gained an increasing role in the discussion about the pros and cons of exchange rate stabilization (McKinnon and Schnabl 2004a, McKinnon and Schnabl 2004b, De Grauwe and Schnabl 2007). There is both a short-term (microeconomic) and a long-term (macroeconomic) perspective which are both based on the fact that underdeveloped capital markets (as they are prevalent in emerging markets and developing countries) make financials institutions vulnerable to exchange rate fluctuations (Eichengreen and Hausmann 1999).

With domestic foreign exchange markets being small and illiquid, most international short-term payment transactions are denominated in international currency. An active forward market in foreign exchange does not exist. ${ }^{1}$ For this reason the foreign exchange risk of short-term capital transactions typically remains un-hedged. Monetary authorities can provide an informal hedge for private short-term capital transactions by minimizing daily exchange rate fluctuations. In practice, formal or informal limits to daily exchange rate fluctuations defined in terms of percent exchange rate changes are established (Chmelarova and Schnabl 2006). These allow private banks and enterprises to repay (reclaim) their short-term foreign currency liabilities (assets) with minimal exchange rate risk.

At low frequencies of exchange rate volatility, the rationale for exchange rate stabilization in debtor countries originates in long-term liability and asset dollarization. If net debt is denominated in foreign currency, sharp depreciations increase the liabilities in terms of domestic currency. The probability of default and crisis increases. (Long-term) exchange rate stabilization is equivalent to reducing default risk on balance sheets (Eichengreen and Hausmann 1999, McKinnon and Schnabl 2004a).

Yet also emerging market creditor countries such as China, Taiwan and Russia have an incentive to stabilize exchange rates as international assets tend to be denominated in international currency. When East Asian investors accumulate assets in US dollars, an appreciation of the domestic currency against the dollar would reduce the value of these assets in terms of the

1 If hedging instruments are available, the cost of hedging dollar liabilities, i.e. the premium on buying dollars forward with the domestic currency, is high. 
domestic currency. The consequence is "fear of appreciation", foreign exchange intervention and reserve accumulation (McKinnon and Schnabl 2004b).

\section{Currency Diversification in International Reserves and Currency Baskets}

Given the rationale for exchange rate stabilization in East Asia as discussed above, it seems unlikely that East Asian countries will pursue fully flexible exchange rates. This will be the case as long as they have not found a way of intra-regional exchange rate stabilization which allows them to float commonly against the euro and the dollar. Instead, they will tend to stabilize exchange rates in the form of tight or soft pegs based on the smoothing of daily, monthly and yearly exchange rate fluctuations.

Figure 3: Exchange Rate Volatility in East Asia and Emerging Europe

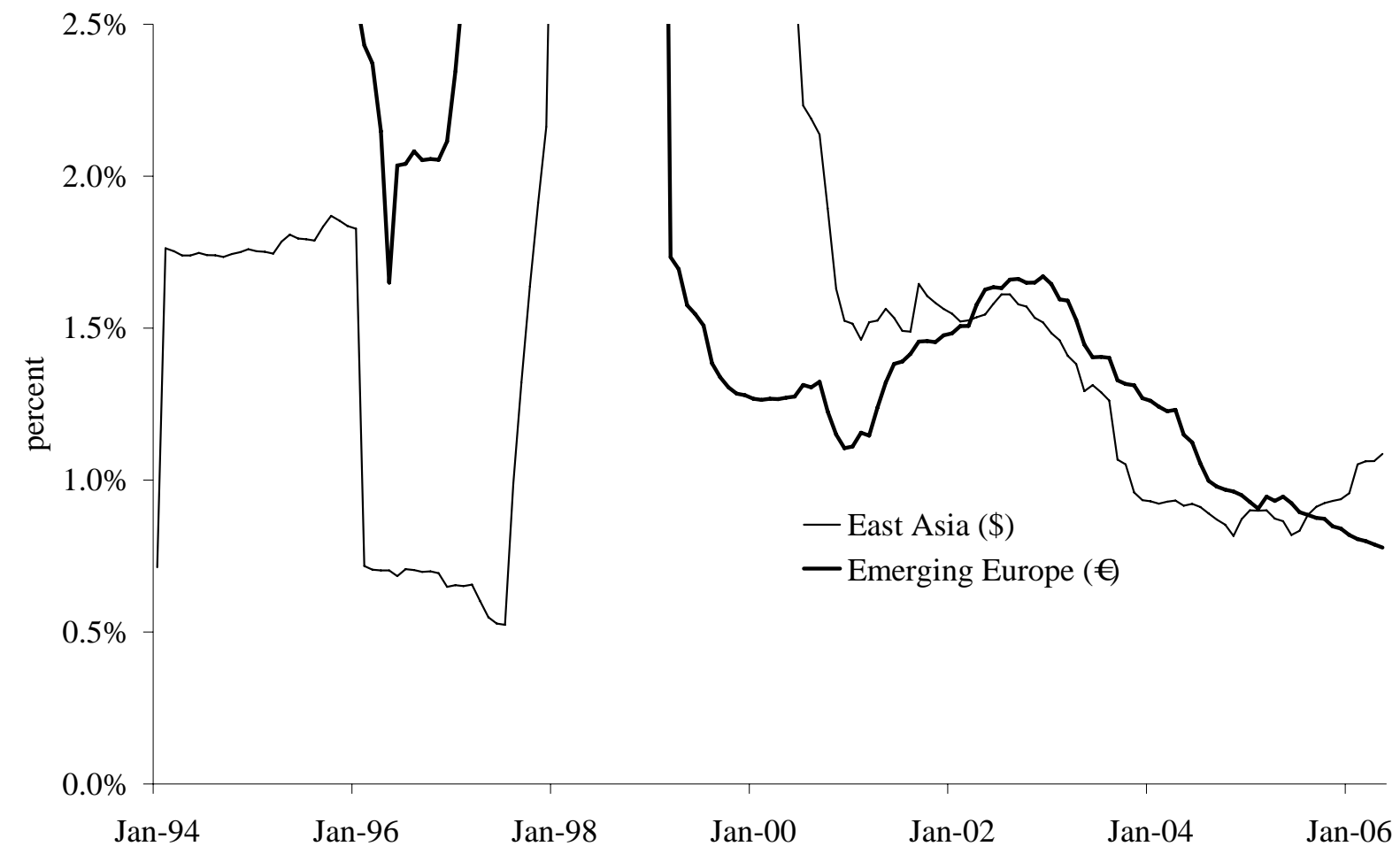

Source: IMF. Regional exchange rate volatility defined as arithmetic averages of two year rolling standard deviations. Emerging Europe comprises 17 (South) Eastern and Central European countries.

McKinnon and Schnabl (2004a) have shown that post-Asian crisis most East Asian countries have returned to their pre-crisis exchange rate stability against the dollar, at least at high frequencies (i.e., day-to-day or week-to-week exchange rate fluctuations). As shown in Figure 3, also measured in arithmetic averages of month-to-month percent exchange rate changes post- 
crisis exchange rate volatility against the dollar has declined gradually up to the year 2004. This finding is in line with the McKinnon (2005) hypothesis of network externalities in favor of the world dollar standard.

\subsection{The Risk of One-Sided Dollar Pegs}

Although the dollar remains the most important anchor currency in the region, Figure 3 also suggests that East Asian exchange rate volatility against the dollar was on the rise in 2005 and 2006 and is now in average more than exchange rate volatility of the (South) Eastern and Central European currencies (emerging Europe) against the euro. This may indicate either a general increase in exchange rate volatility as advocated by the IMF (Fischer 2001) or a (gradual) change in the anchor currencies. The main alternative anchor currencies are the euro, the Japanese yen or both.

Frankel and Chinn (2005) and Galati and Wooldrige (2006) argue that the role of the dollar as an international currency may be challenged by the euro, depending on the long-term inflation expectations for the US economy. In East Asia, the degree of macroeconomic stabilization, which is achieved via exchange rate pegs, hinges not only on domestic efforts to keep the exchange rate stable against the anchor currency but also on the monetary policy in the anchor country.

While low and stable US inflation has been a crucial prerequisite for the rise of the dollar as an international currency, the degree of US price stability has fluctuated over time. Since the late 1960s, the US dollar has experienced several phases of rising inflation and sustained depreciation pressure. During these periods a relatively loose US monetary policy was transmitted via reserve accumulation into rising inflationary pressure in countries stabilizing their currencies against the US dollar.

Back in the late 1960s and early 1970s, an expansionary fiscal and monetary stance in the US contributed to a world-wide increase in inflation, which finally triggered the breakdown of the Bretton Woods system. While the European currencies were de-linked from the dollar (thereafter stabilizing their exchange rates against the German mark), most countries outside of Europe, for instance those in East Asia, continued to peg their currencies more or less tightly to the dollar. The international role of the dollar was enhanced by its dominant role as an invoicing currency 
for international trade, the deepness of US capital markets, and the lack of alternative international currencies (McKinnon 2005). This has led Dooley, Folkerts-Landau, and Garber (2004) to argue that the United States is at the center of what they have called a revived (informal) Bretton Woods system.

Reminiscent of the early 1970s, in the new millennium an exceptionally loose fiscal and monetary stance under the Bush administration has triggered a discussion about the impact of fast reserve accumulation on the countries stabilizing their exchange rates against the dollar. When the Federal Reserve kept the interest rate at historically low levels from 2001 to 2004, the dollar came under strong depreciation pressure. As many countries continued to stabilize exchange rates against the dollar they accumulated (and continue to accumulate) large amounts of dollar reserves. Figure 4 shows the substantial degree of reserve accumulation in East Asia, which has accelerated in many countries since 2001, most dramatically in China, Korea, Malaysia, and Japan.

While fast reserve accumulation has the benefit of strengthening the credibility of the exchange rate pegs, it has two main downsides. First, as under fixed exchange rates the scope for sterilization of foreign exchange intervention is limited, the East Asian countries have experienced fast monetary expansion. Although inflation has been contained in most countries so far, the fast growth of monetary aggregates has contributed to surging stock and real estate prices. An eventual burst of such "bubbles", for instance in China, may result in cumbersome recessions like those experienced in the Asian crisis countries and in Japan since the early 1990s.

Second, as outlined above for countries with sustained current account surpluses, rising world inflation has a negative impact on the real value of export revenues and international dollar denominated assets. If, as in the case for many commodity exporting countries, export revenues are earned in dollars and spent on imports from the euro area, dollar depreciation against the euro erodes the real purchasing power of the dollar denominated earnings. Thus for international creditor countries, such as Japan, China, Russia and Taiwan the appreciation of domestic currencies reduces the value of these assets in terms of domestic currencies (Section 2) as well as in terms of purchasing power in third currencies. 
Figure 4: Official Foreign Exchange Reserves in Billions of Dollars, 1980:01-2006:02 (Monthly)

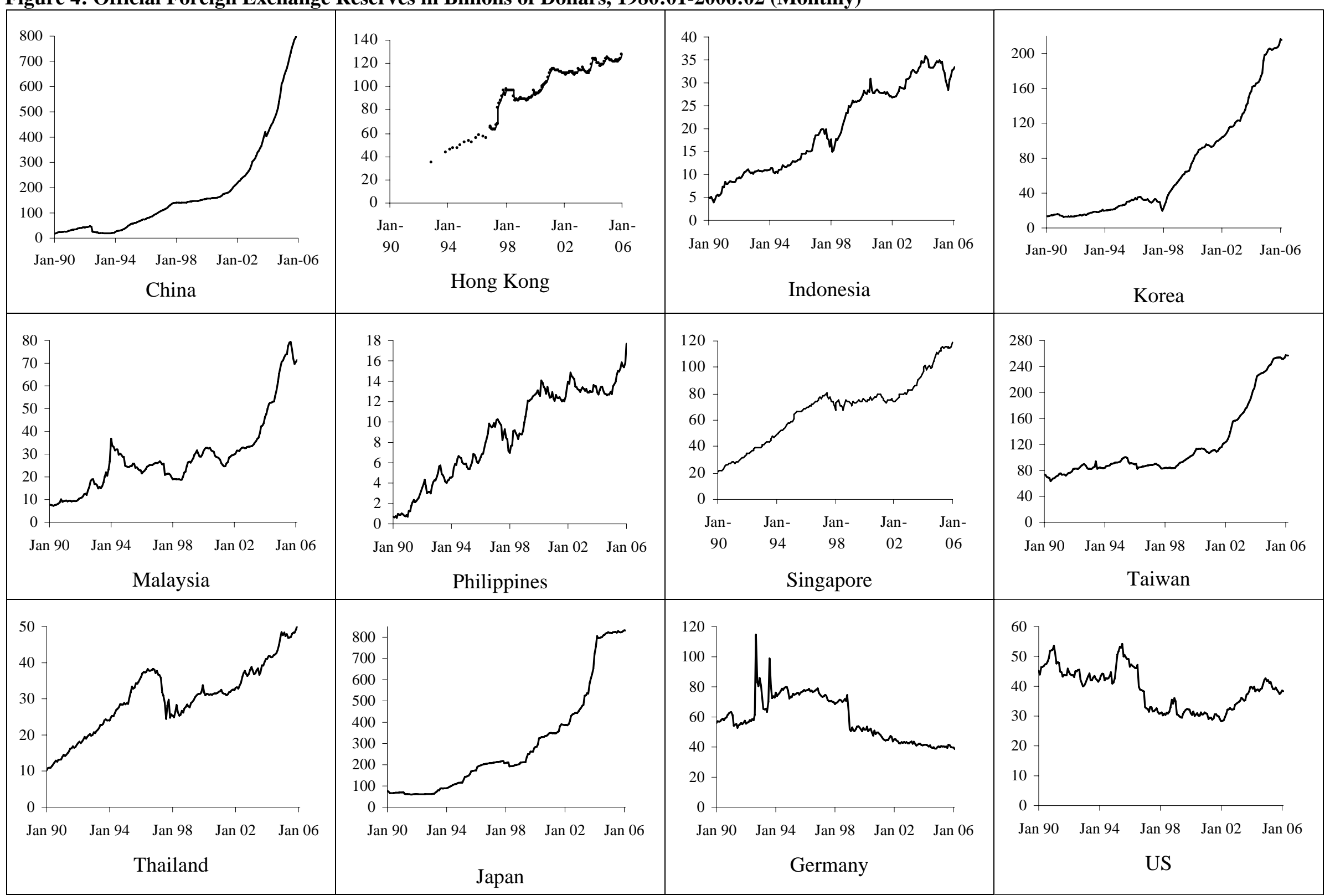

Source: IMF: IFS. Billion dollars. Note different scales on the y-axis. 
The upshot is that, between 2001 and 2004, private and public investors reacted asymmetrically to the sustained dollar depreciation. As the sharply rising US current account deficit went along with rising current account surpluses in countries stabilizing their exchange rates against the dollar, private investors tended to convert dollar positions into domestic currencies, bringing their domestic currencies under appreciation pressure. In contrast, the monetary authorities in many emerging markets in East Asia, the Middle East, Latin America, and the CIS tended to resist this appreciation pressure via foreign exchange intervention. From the perspective of the monetary authorities, this "leaning against the wind" in the build-up of international assets was fully rational because it shielded the export industries against appreciation and maintained the nominal value of the large stocks of international dollar assets. Both factors contribute to macroeconomic stability.

In the longer-term, however, the monetary authorities of East Asian countries may change their exchange rate targets. If they expect the depreciation of the dollar to continue, they may consider reducing the dependency on the dollar as an anchor and reserve currency (Chinn and Frankel 2005 and Eichengreen 2005). The current expectations about the future value of the US dollar hinge on the expected macroeconomic policies in the US. Starting from 2004, the interest rate increases of the Federal Reserve helped to sustain the value of the dollar, which appreciated against most currencies during 2005. Yet if the US fiscal deficit and the low private savings rate are expected to continue, and if a burst of the current "real estate bubble” seems likely, the future federal funds rate may be expected to decline again. The implication would be a higher level of US inflation and further depreciation pressure on the dollar.

\subsection{Diversification of Risk}

If central banks around the world that have in the past used the dollar as the predominant anchor and reserve currency see a significant probability of a sustained dollar decline, they will consider reducing their dependency on the US currency (Eichengreen 2005). In contrast to former periods of dollar depreciation such as in the 1970s, today the euro has become a viable competitor as an anchor and reserve currency (Chinn and Frankel 2005, ECB 2005, Lim 2006). Although the integration of the European financial markets is still lagging behind the US, deep and liquid euro capital markets provide a broad variety of investment opportunities (Galati and Wooldrige 2006). In addition, the European Central Bank may be perceived as more inflation-averse than the 
Federal Reserve, which would further strengthen the attractiveness of the euro as an international currency. $^{2}$

Instead of solely pegging to the dollar, the East Asian countries may peg to a basket of currencies for several reasons. Williamson (2000 and 2005) has proposed that a currency basket for the East Asian countries should reflect the direction of trade (rather than the currency denomination of trade). The benefits would be nominal effective exchange rate stability ${ }^{3}$ and lower fluctuations of overall trade (Gudmundsson 2005). The weights of such a currency basket would closely reflect the trade structure of the respective countries, giving substantial weights to the dollar, the yen, and the euro as well as to smaller East Asian currencies such as the Korean won, the Malaysian ringgit, and the Chinese yuan. ${ }^{4}$

In particular, Japan is one of the most important trading partners of the smaller East Asian countries and an important competitor in third markets for the more advanced East Asian economies such as Korea and Taiwan. For instance, the strong depreciation of the Japanese yen against the dollar after 1995 (when the smaller East Asian countries kept their exchange rates tightly pegged to the dollar) contributed to the Asian crisis (McKinnon and Schnabl 2003).

For this reason, Kawai (2002) has proposed that the yen should be given a prominent weight in the East Asian currency baskets in order to maintain intra-East Asian exchange rate stability. Ogawa and Ito (2002), reflecting the argument of McKinnon and Schnabl (2004a) that the common peg of the East Asian currencies to the dollar contributed to the stabilization of intraregional exchange rates and thereby fostered intra-regional trade, have proposed a coordination of the weights of all East Asian currency baskets. This could be achieved by Williamson's (2005) and Kawai’s (2006) proposition that dollar, yen, and euro should be (by and large) treated equally in the East Asian exchange rate strategies.

In addition to this purely trade-oriented approach, there is also a case for pegging to a basket of currencies from the point of view of macroeconomic stabilization. As shown above, since 2001

2 Schnabl (2006) shows how the Central Bank of Russia has promoted the role of the euro as anchor, intervention and reserve currency since early 2005.

3 For small countries that have one major trading partner, it makes more sense to peg to only one currency instead of a basket.

4 In July 2005 China announced a currency basket which claimed to contain dollar, yen and euros as well as a substantial number of smaller currencies such as the Korean won, the Thai baht, the Malaysian ringgit, the Russian rouble, the Canadian dollar, amongst others. 
the tight pegs to the dollar in East Asia have contributed to a fast accumulation of foreign reserves. With underdeveloped capital markets and free capital flows, the scope for sterilization of foreign exchange intervention is limited. The respective expansion of the money supply may be regarded as a threat to price and macroeconomic stability. Asset market bubbles may emerge.

Given exchange rate stabilization, the domestic price level can be regarded as a function of the price level of the anchor country. In the case of a currency basket, the domestic price level would be a function of the price levels of all anchor countries which are represented in the basket. From this perspective the East Asian countries would be inclined to give a higher weight to currencies which are regarded as particularly stable. The Japanese yen may not qualify as an anchor currency as long as the (close to) zero interest rate policy and deflation continue. The euro certainly would.

Furthermore, the expectations about the longer-term stability of specific anchor currencies will also have an impact on the choice of the currency composition of foreign reserves. In the past, the foreign reserves of the East Asian countries were widely considered to be denominated mostly in US dollars, as international transactions in East Asia were dollarized and exchange rates were stabilized against the dollar. Network externalities matter as governments tend to hold reserves in the currency in which they intervene. This is the US dollar as the most important international currency in the region.

Nevertheless, if the East Asian central banks expect a further depreciation of the dollar, they may wish to diversify their portfolio of international currencies (Eichengreen 2005). Then, it may be worth tolerating slightly less market liquidity in the euro capital markets in return for the benefits of more diversification. This would imply that higher weights are given to the euro (and the yen). This can be achieved with the help of two strategies. First, while pegging against the US dollar continues (causing foreign reserves to be accumulated in US dollars), dollar reserves can be converted into euro reserves. ${ }^{5}$ Although the peg against one anchor currency would be compatible with a diversification of reserves, the downside of this strategy is that dollar sales would put further depreciation pressure on the dollar and therefore would require additional foreign exchange intervention. This effect could be avoided if the restructuring of the currency

If large countries such as China and Japan would start converting dollars into euros this could have a strong destabilizing effect on the dollar. To avoid such an effect, countries may tend to maintain their dollar stocks but built up new reserve position in euros. 
structure of official foreign reserve holdings were to take place in times of dollar appreciation, as was the case in 2005.

Although there is no direct need to give different currencies similar proportions as anchor and reserve currencies, countries may strive to "harmonize” the currency structure of the foreign assets with the weights of the currencies in their intervention baskets. Gudmundsson (2005) argues that many central banks use a minimum variance analysis to determine their reserve compositions. This implies that reserve structures mirror intervention basket structures in order to reduce nominal fluctuations of the value of the international reserves. For instance, Russia had given the dollar a weight of $60 \%$ in foreign reserves and $65 \%$ in the currency basket in mid2005, giving the euro weights of 33\% and 35\%, respectively (Schnabl 2006).

To this end, the desire to diversify the currency denomination of international reserves may enhance the role of the euro as an anchor currency. This implies a causal relation between policy goals concerning the reserve composition and the desired exchange rate target. Exchange rate stabilization based on basket strategies also would allow full hedging of the foreign exchange risk of international payments flows, as uncertainty only originates in the exchange rate fluctuations between the dollar, the euro, and the yen. For these exchange rate fluctuations, the highly developed capital markets in Japan, the US, and the euro area provide sufficient tools for hedging the foreign exchange risk.

\section{Estimation of Baskets Structures}

Has the structure of the East Asian currency baskets changed recently as suggested by Kawai (2006)? Frankel and Wei (1994) have proposed an OLS estimation which allows for the tracking of the structures of undisclosed currency baskets as they prevail in East Asia. The empirical analysis of the currency basket structures in East Asia proceeds in two stages. First, we test for the basket structures before the Asian crisis, which are expected to reveal a strong US dollar weight. Second, based on a rolling window approach, possible changes in basket structures are identified. 
Following Frankel and Wei (1994), an "outside” currency—the Australian dollar — —is used as a numéraire for measuring exchange rate volatility in the East Asian currencies (except the yen). This volatility can be partitioned into movements in major currencies against the Australian dollar. For example, if changes in the Korean won against the Australian dollar are largely explained by changes in the US dollar against the Australian dollar, the US dollar has very high weight in the Korean currency basket. The exchange rates of each of the nine East Asian currencies are regressed on the US dollar, the Japanese yen, and the euro ${ }^{7}$ with the Australian dollar as numéraire:

$$
e_{\text {EastAsianarrencyAUD }}=\alpha_{1}+\alpha_{2} e_{\text {DollarAUD }}+\alpha_{3} e_{\text {YenAUD }}+\alpha_{4} e_{\text {EuroAUD }}+u_{t}
$$

The multivariate OLS regression ${ }^{8}$ is based on first differences of logarithms in the exchange rate $e$. The residuals are controlled for heteroscedasticity. The daily data are compiled from Bloomberg. The $\alpha$ coefficients represent the weights of the respective currencies in the currency basket. If the East Asian currency is closely fixed to one of the major currencies appearing on the right hand side of equation (1), the corresponding $\alpha$ coefficient will be close to unity. If a coefficient is close to zero, there is no exchange rate stabilization against that particular currency.

\subsection{The Pre-Crisis Currency Baskets}

First, as in McKinnon and Schnabl (2004a) we estimate the composition of East Asian countries' currency baskets for the pre-Asian crisis period, which starts in February 1994 when China unified its foreign exchange market and ends in May 1997 before the first major turbulence (869 observations). Table 1 reports the results, showing the high weights of the dollar in the East Asian currency baskets. The estimates for $\alpha_{2}$ are all close to unity, ranging from 0.82 for the Singapore dollar up to 1.00 for the Chinese yuan, the Hong Kong dollar, and the Indonesian rupiah. The correlation coefficients $\left(\mathrm{R}^{2}\right)$ being close to unity indicate that fluctuations of the East

\footnotetext{
6 In former estimations we used the Swiss franc as a numéraire. Yet since the Swiss franc might be linked to the euro, we use the Australian dollar here.

7 Before January 1999 the euro is represented by the German mark as the most important currency of the European Monetary System.

8 There is no evidence for any co-integrating vector between the four exchange rate levels.
} 
Asian currencies' exchange rates against the Australian dollar can almost fully be explained by fluctuations of the dollar against the Australian dollar.

The results show that high dollar weights also can be achieved under a downward crawling peg arrangement, as in Indonesia before May 1997. The $\alpha_{2}$ coefficients of the Korean won, the Philippine peso, and the Taiwan dollar are very close to unity with lower, but still large, tstatistics. For the Thai baht and the Malaysian ringgit, the $\alpha_{2}$-coefficients are still close to 0.9.

Table 1: Pre-Asian Crisis East Asian Currency Basket Structures (1.1.1994-30.5.1997)

\begin{tabular}{|c|c|c|c|c|c|}
\hline & Constant $\alpha_{1}$ & Dollar $\alpha_{2}$ & Yen $\alpha_{3}$ & $\mathbf{D M} \alpha_{4}$ & $\mathbf{R}^{2}$ \\
\hline \multirow[t]{2}{*}{ Chinese Yuan } & -0.00 & $1.01 * * *$ & -0.01 & -0.02 & 0.97 \\
\hline & $(-1.15)$ & (158.63) & $(-1.48)$ & $(-1.70)$ & \\
\hline \multirow[t]{2}{*}{ Hong Kong Dollar } & 0.00 & $1.00 * * *$ & 0.00 & -0.01 & 1.00 \\
\hline & $(0.30)$ & $(454.79)$ & $(0.25)$ & $(-1.36)$ & \\
\hline \multirow[t]{2}{*}{ Indonesian Rupiah } & 0.00 & $1.00 * * *$ & -0.01 & 0.01 & 0.97 \\
\hline & (3.19) & (144.93) & $(-0.92)$ & $(0.85)$ & \\
\hline \multirow[t]{2}{*}{ Korean Won } & 0.00 & $0.97 * * *$ & $0.06 * * *$ & 0.01 & 0.93 \\
\hline & $(1.42)$ & $(66.27)$ & (3.31) & $(0.29)$ & \\
\hline \multirow[t]{2}{*}{ Malaysian Ringgit } & -0.00 & $0.88 * * *$ & $0.09 * * *$ & 0.01 & 0.90 \\
\hline & $(-1.48)$ & $(54.80)$ & (5.30) & $(0.45)$ & \\
\hline \multirow[t]{2}{*}{ Philippine Peso } & -0.00 & $0.97 * * *$ & 0.02 & -0.01 & 0.86 \\
\hline & $(-0.34)$ & $(43.34)$ & $(0.74)$ & $(-0.45)$ & \\
\hline \multirow[t]{2}{*}{ Singapore Dollar } & -0.00 & $0.82 * * *$ & $0.14^{* * *}$ & $0.08 * * *$ & 0.86 \\
\hline & $(-1.32)$ & (34.37) & $(4.83)$ & (2.97) & \\
\hline \multirow[t]{2}{*}{ New Taiwan Dollar } & 0.00 & $0.98 * * *$ & $0.03 * *$ & -0.01 & 0.93 \\
\hline & $(0.84)$ & (57.30) & (1.38) & $(-0.54)$ & \\
\hline \multirow[t]{2}{*}{ Thai Baht } & -0.00 & $0.92 * * *$ & $0.08 * * *$ & -0.01 & 0.95 \\
\hline & $(-0.61)$ & (81.25) & (5.17) & $(-0.35)$ & \\
\hline
\end{tabular}

Source: Bloomberg. Daily data. T-Statistics in Parentheses. ** significant at the $5 \%$ level. *** significant at the 1\% level. 869 observations. White heteroscedasticity-consistent standard errors \& covariance.

Singapore shows the lowest weight for the dollar (82\%) and smaller (but highly statistically significant) weights for the yen (14\%) and the German mark (8\%). There is some evidence of small weights for the yen in the pre-crisis East Asian currency baskets of Korea (6\%), Malaysia (9\%), Singapore (14\%), Taiwan (3\%), and Thailand (8\%). However, except for Singapore there 
is no evidence of exchange rate stabilization against the German mark. All in all, before the Asian crisis East Asia can be characterized as adhering to an informal dollar standard (McKinnon 2005).

\subsection{Changing Currency Structures}

As outlined in Section 3, after the Asian crisis it has been recommended to increase the weight of the Japanese yen in the East Asian currency baskets to minimize macroeconomic turbulence caused by bilateral exchange rate fluctuations against the Japanese yen. There may be a rationale to include the euro into the currency baskets, not only because of trade linkages with the European Union but primarily because of the wish to diversify international reserves. The years 2005/06 would have been an optimal time for reshuffling the currency structure of international reserves as the dollar was strong against the euro due to rising US interest rates. In times of dollar appreciation, dollar sales would not trigger a run out of the dollar which would devalue the remaining dollar assets.

Using rolling regressions, the country panels in Figure 5 summarize the dollar's weight in each East Asian currency basket since the early 1990s. Based on daily data, the rolling 130-day $\alpha_{2}$ coefficients are plotted for each of the East Asian countries (except Japan). A window of 130 days corresponds to an observation period of six months (5 observations per week). The first window starts on January 1, 1990 and ends on June 29, 1990. The $\alpha_{2}$ coefficient is calculated for the first period. Then the window is shifted by one day and the coefficient is calculated again, up to August 2006. A value of unity stands for a 100 percent weight of the respective currency in the respective currency basket.

Figure 5 shows the time path of the dollar weights in the East Asian currency baskets. For all countries, as suggested by Table 1 , the weight of the dollar has been very high and (close to) unity before the Asian crisis. The Asian crisis is marked by a sharp decline of the $\alpha_{2}$ coefficient in many East Asian countries (except China and Hong Kong). This phenomenon represents the crisis and (strong) depreciations of the East Asian currencies. Post-crisis, it seems that the weights of the dollar in the East Asian currency baskets have evolved differently. 
Figure 5: Dollar's Weight in East Asian Currency Baskets: 130-Trading-Day Rolling Regressions for $\alpha_{2}$, 1990:01-2006:08 (Daily)

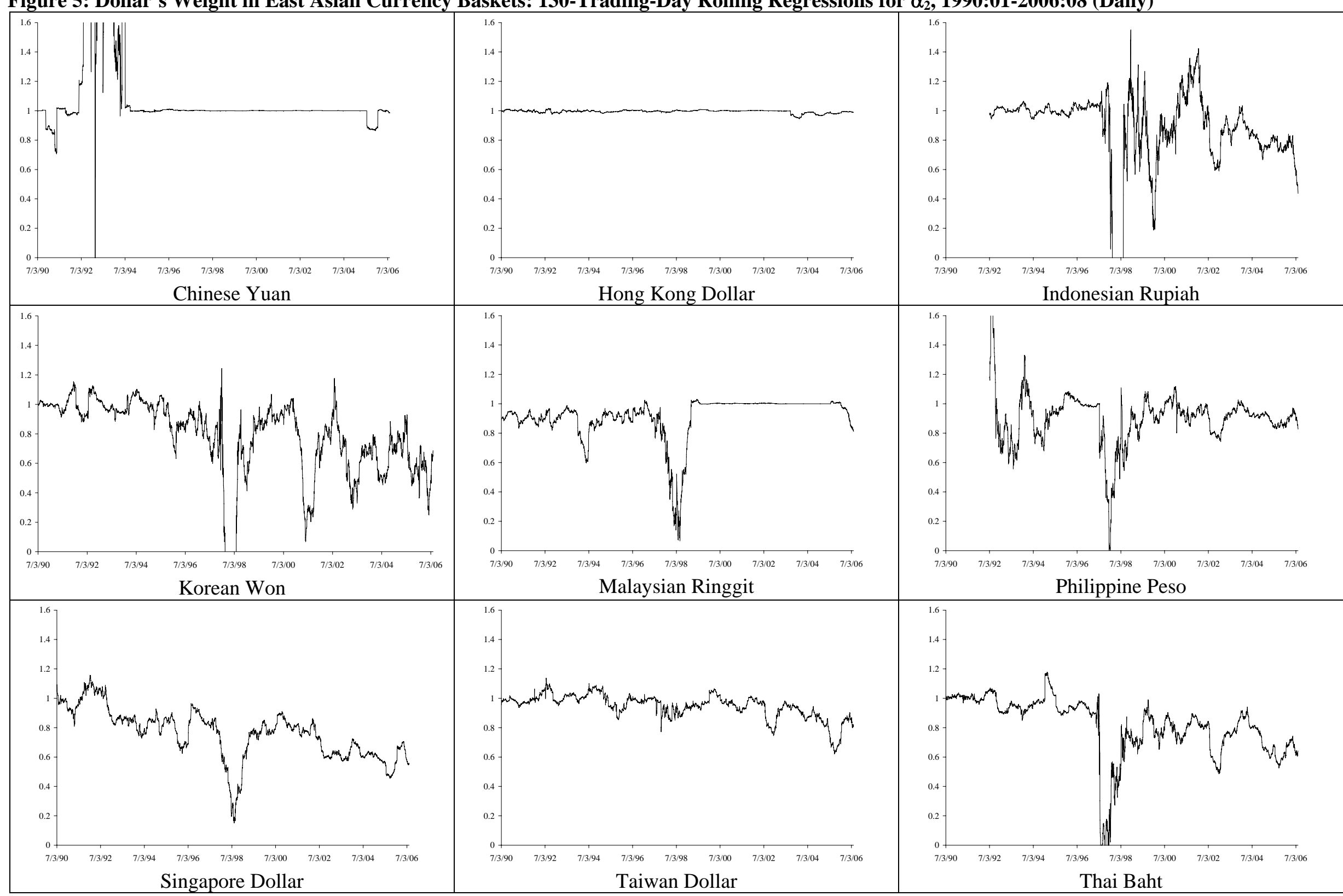

Datasource: Bloomberg. 1 corresponds to 100\%. Note: A $\alpha_{2}$-coefficient close to unity shows $100 \%$ weight for the dollar in the currency basket. 
First, China and Hong Kong have very stable dollar weights (close) to unity. Officially shifting toward a currency basket regime in July 2005, China seems to have decreased the weight of the dollar in its basket slightly since then. The sudden decline of the coefficient in the second half 2005 is due to the one-time 2.1\% appreciation of the yuan against the dollar (and other currencies) on July $21^{\text {st }} 2005$. This effect fades out after the July $21^{\text {st }}$ value leaves the estimation window in early 2006. Since then, the weight of the dollar seems to have decreased only very marginally.

In contrast, in Malaysia, which has allowed for more exchange rate flexibility since July 2005, the weight of the dollar seems to have declined significantly. The estimated weight of the dollar declined from 100\% in early 2005 down to about 80\% in August 2006. The trend seems to point further downward. For Indonesia, Korea and the Philippines the coefficients are rather volatile. This may indicate either high volatility in the foreign exchange market or sudden exchange rate changes. Nevertheless, particularly in Korea the weight of the dollar in the currency baskets exhibits a strong downward trend. While in the early 1990s the weight of the dollar was close to unity, in the year 2006 the weight seems to have declined to about 50\%. This indicates a shift in the basket structure rather than more exchange rate flexibility, because at the same time the stock of Korean foreign reserves increased considerably (Figure 4).

Also for Singapore, Taiwan and Thailand, there seems to be a clear downward trend of the dollar weights in the respective currency baskets. While for all three countries the weight was close to unity in the early 1990s, by 2006 it was around 80\% in Taiwan, 70\% in Thailand, and 60\% in Singapore. For all three countries the trend is pointing downwards. To this end, Figure 5 provides evidence that - although the dollar remains the prominent anchor currency in East Asia - its role seems to decrease. There is no evidence that this downward trend has faded out recently. As the dollar weights in the East Asian currency baskets have become rather heterogeneous, intra-regional exchange rate volatility in East Asia is increasing.

The appreciation of the dollar in 2005 provided a good occasion to shift the structure of the currency baskets away from the dollar toward the yen or the euro. Estimating the rolling weights of both currencies in the East Asian currency baskets are complementary tests for possible changing structures. Figure 6 shows the results for the Japanese yen. As shown by McKinnon and Schnabl (2003) one major reason for the Asian crisis has been the depreciation of the Japanese yen against the US dollar and the East Asian currencies which were pegged to the 
dollar. To avoid a decline of competitiveness against Japanese exporters in the domestic and third markets, the East Asian countries may increase the weights of the Japanese yen to reduce long-term exchange rate fluctuations against the Japanese currency.

Figure 6 provides evidence in favor of a growing role of the Japanese yen in the East Asian currency baskets. ${ }^{9}$ Although the $\alpha_{3}$ coefficients are rather volatile there is a clear upward trend for Korea, Singapore, Taiwan and Thailand. In these countries, the yen seems to have gained weights between $20 \%$ and $30 \%$ by 2006. In Malaysia the weight of the yen seems to have increased from zero in July 2005 to about 10\% in August 2006. In China despite the tight peg to the dollar a very small weight seems to be given to the Japanese yen very recently. ${ }^{10}$ For Indonesia and the Philippines no clear trend can be recognized although for Indonesia the $\alpha_{3^{-}}$ coefficients are significantly higher for the yen after the Asian crisis than before. Hong Kong clearly adheres to its tight dollar peg.

All in all, Figure 6 provides evidence of a growing role for the Japanese yen as anchor currency in East Asia. The motivation is likely to be driven by strong trade linkages with Japan, concerns about competition in third markets (US) and rising attempts to achieve East Asian monetary integration. $^{11}$

Finally, the role of the euro in the East Asian currency baskets is traced. In Figure 7, the time scale starts in the 1999 when the euro was introduced. Before 1999, as shown in Table 1 (with the exception of Singapore) the German mark did not play a major role as an anchor currency in East Asia (McKinnon and Schnabl 2004a). Also after January 1999, the rolling window estimations do not reveal a specific trend as it is observed for the Japanese yen. For three countries, China, Hong Kong and Malaysia, the euro seems not to play any role for the exchange rate policies at all.

\footnotetext{
$9 \quad$ Note the different scale compared to Figure 5.

10 The spike in mid 2005 captures the one time appreciation against the dollar, rather than a change a higher weight of the yen in the currency basket.

11 Kawai (2006) shows the prospects of East Asian monetary integration.
} 
Figure 6: Yen's Weight in East Asian Currency Baskets, 130-Trading-Day Rolling Regressions for $\alpha_{3}$, 2005:01-2006:08 (Daily)
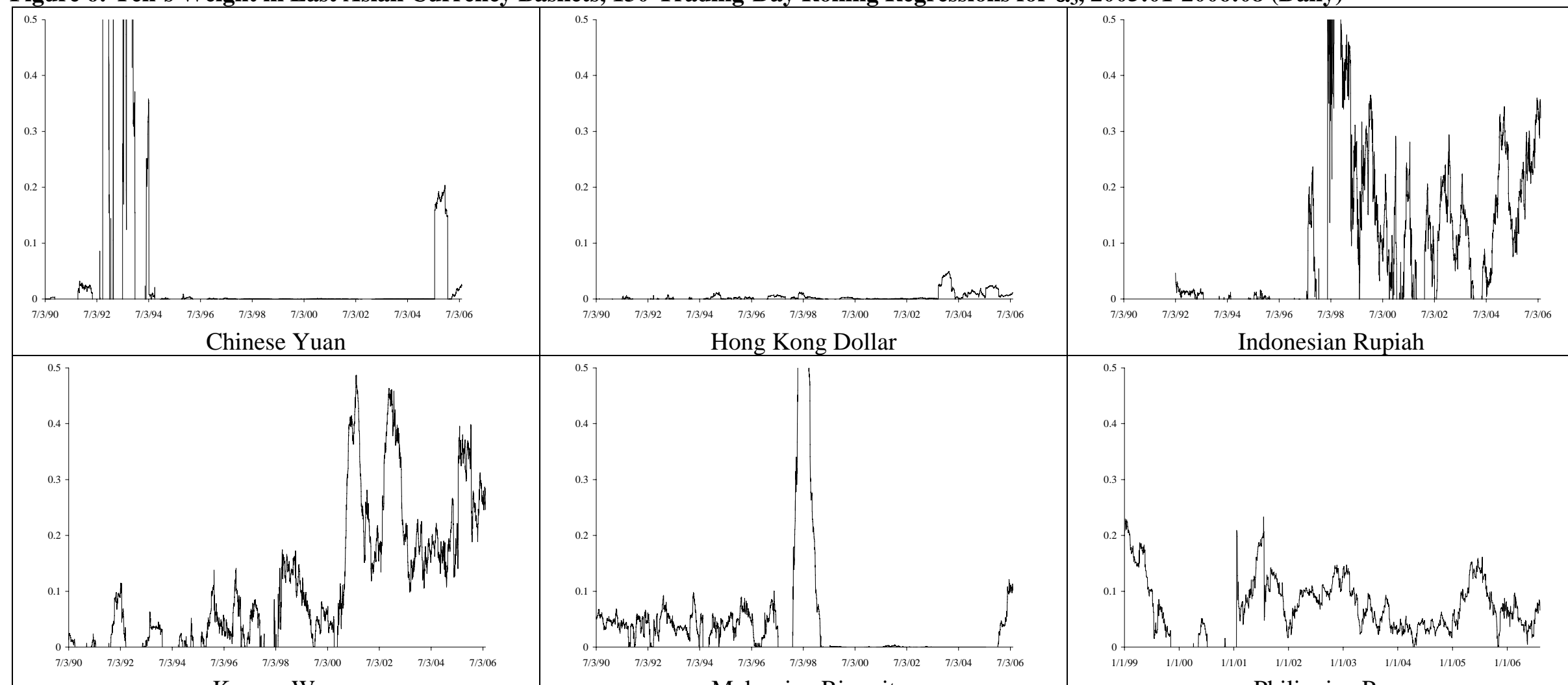

Hong Kong Dolla

Indonesian Rupiah

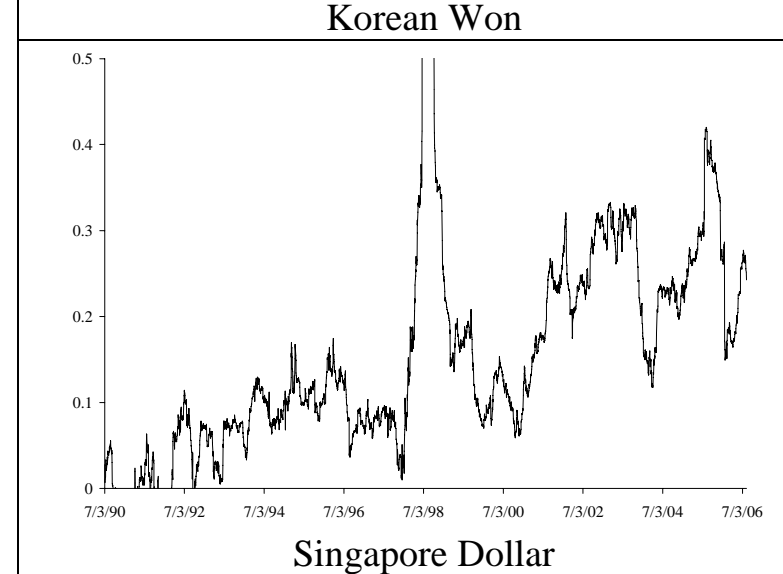

Data source: Bloomberg. 1 corresponds to $100 \%$.

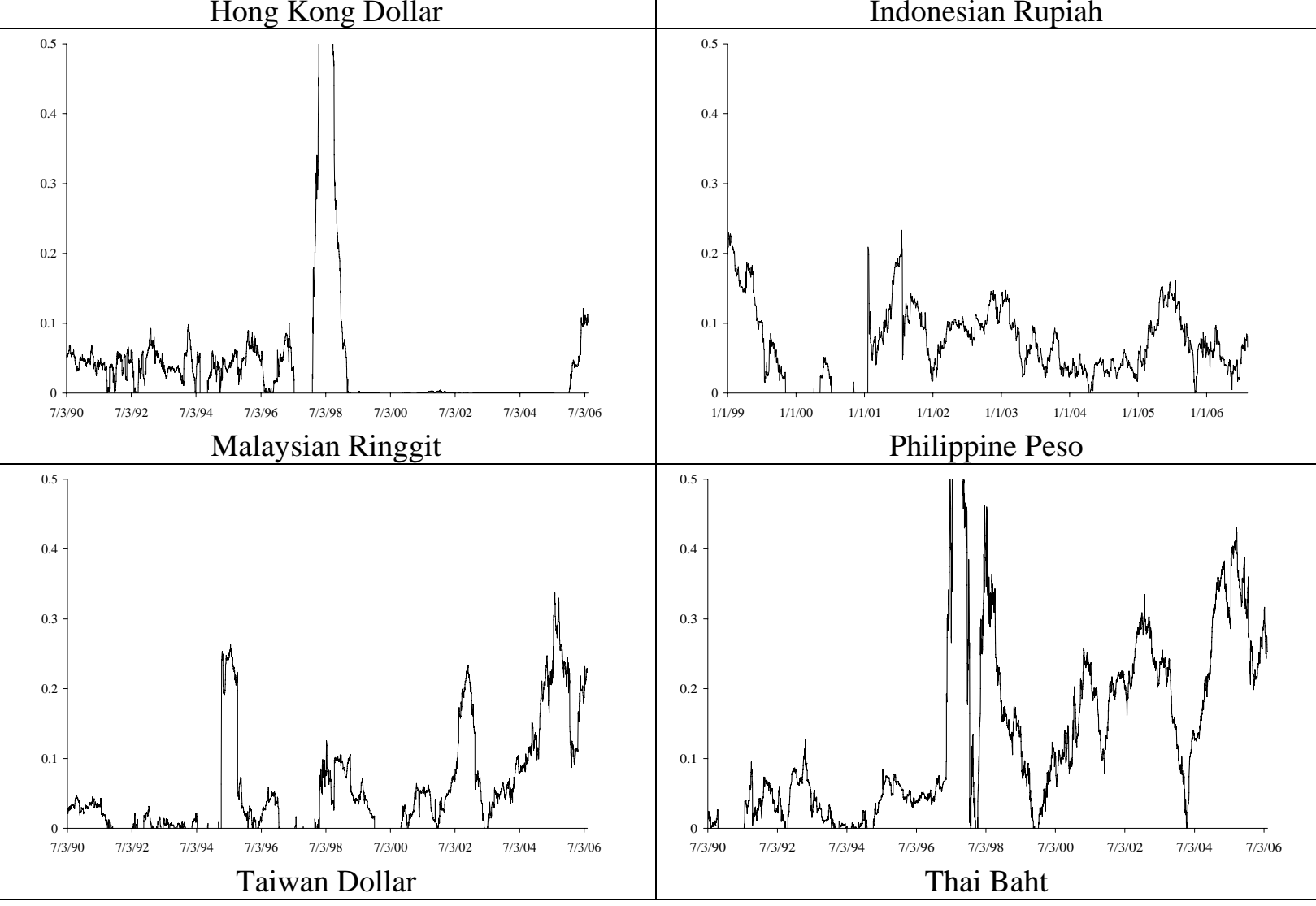


Figure 7: Euro's Weight in East Asian Currency Baskets: 130-Trading-Day Rolling Regressions for $\alpha_{4}$, 1999:01-2006:08 (Daily)

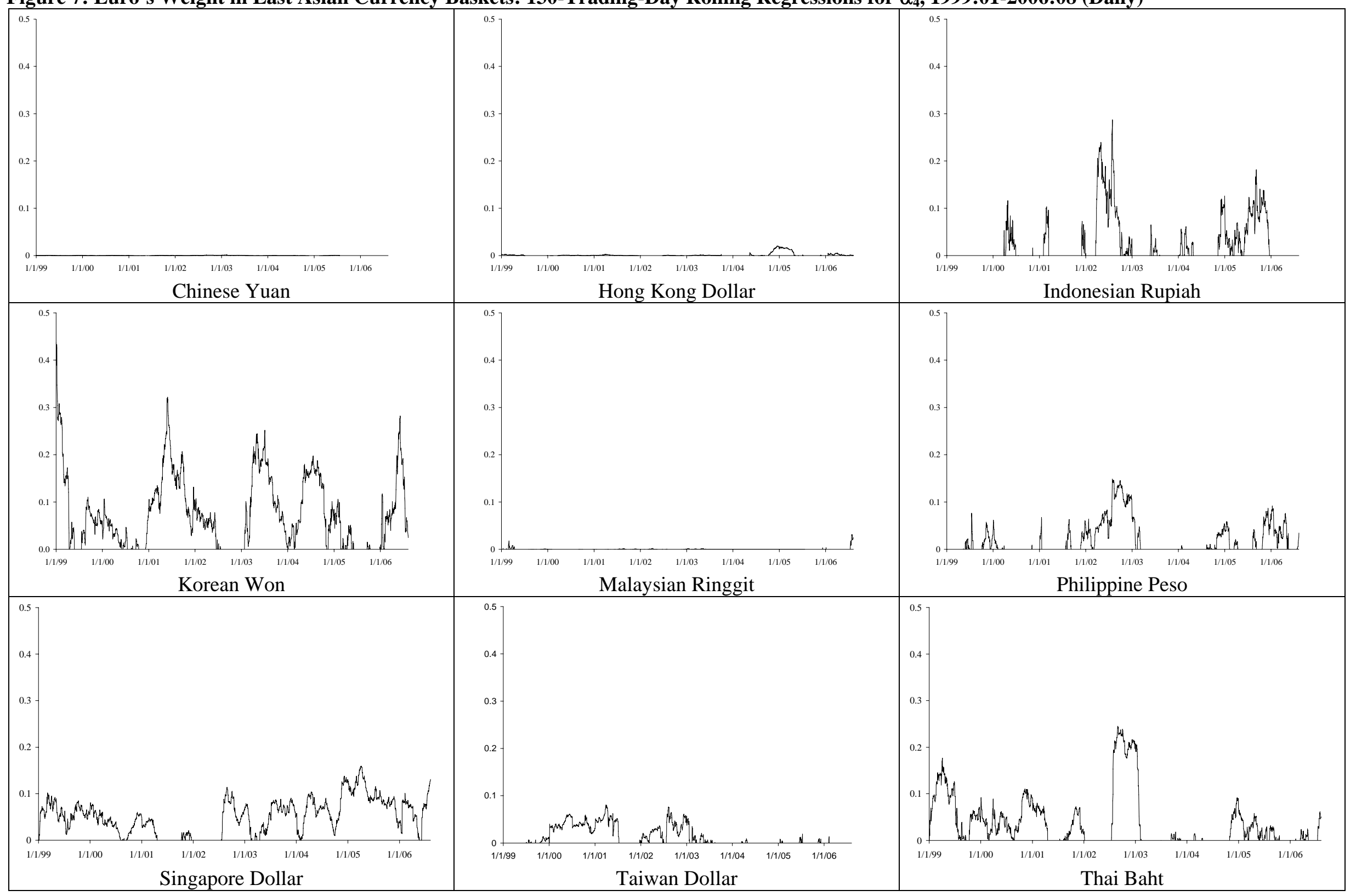

Data source: Bloomberg. 1 corresponds to $100 \%$. 
For all other countries there are spikes in the coefficients, which after a certain time period fade out again. This may allow two interpretations. First, the spikes represent a certain weight of the euro in some East Asian currency baskets. This hypothesis is most likely for Singapore where the coefficient is comparatively stable and the German mark turned out significant in previous estimations (Table 1). For the other currencies the evidence seems less robust. The spikes may represent temporary euro purchases (to change the currency structure of foreign reserves) but not changes in the structure of the currency baskets itself.

Finally, to obtain a comprehensive picture of the structure of currency baskets in East Asia, we calculate arithmetic averages of the weights of the dollar, the yen, and the euro in the currency baskets of the nine East Asian countries (except Japan) during 2005. The result as shown in Figure 8 implies a rising weight for the Japanese yen in the East Asian currency baskets but less for the euro.

Figure 8: The Changing East Asian Currency Structure in 2005

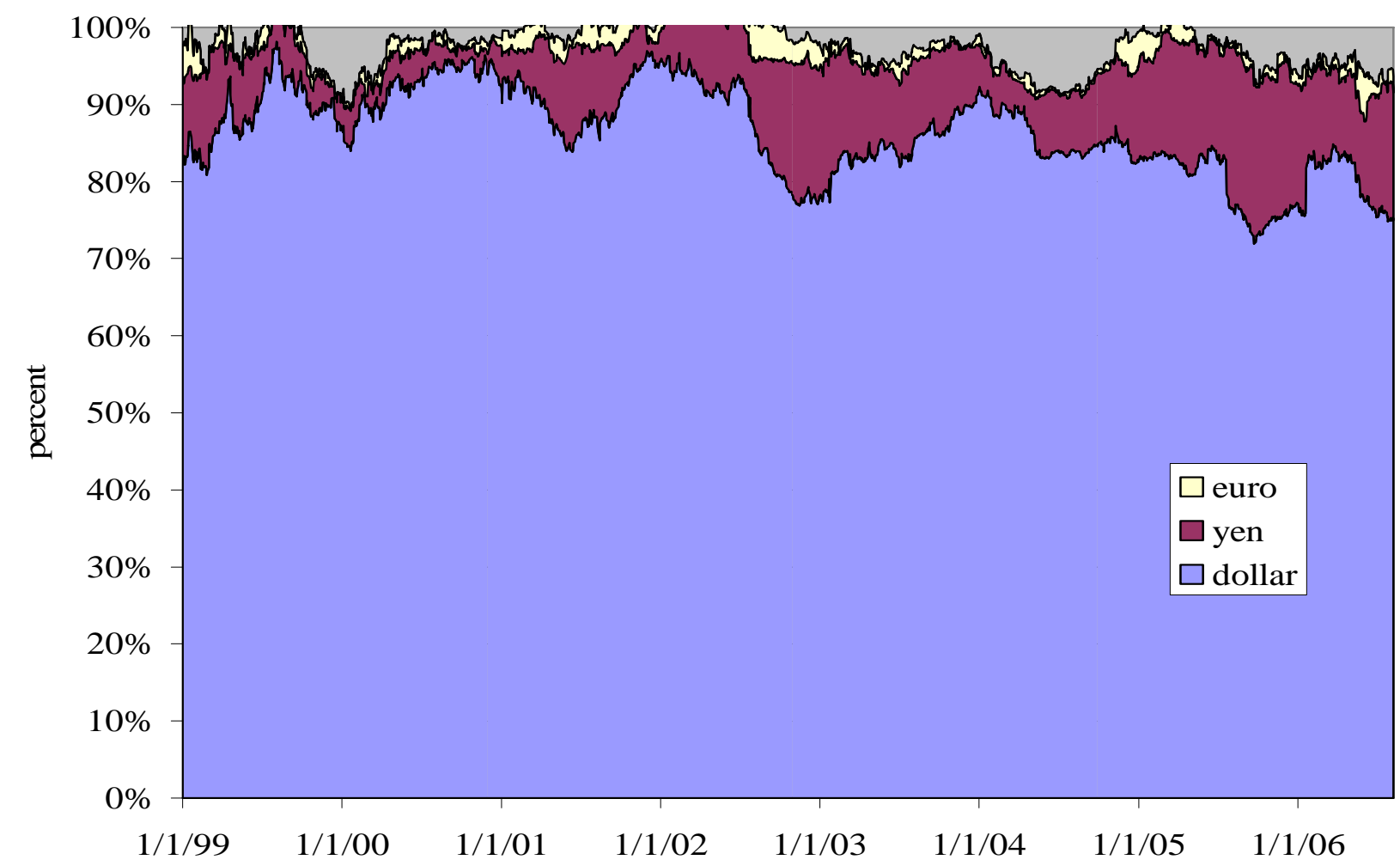

Data Source: Bloomberg. Arithmetic averages of the $\alpha$-coefficients. 


\section{Conclusion}

Before the 1997/98 East Asian crisis, the East Asian countries (except Japan) pegged their currencies tightly to the dollar, forming an informal dollar standard. As the motivations for pegging to the dollar-i.e., macroeconomic stabilization, dollar denomination of international and intra-regional trade, and capital flows-remained unchanged after the crisis, the East Asian countries (except Japan) have returned to their dollar pegs.

However, the sustained depreciation pressure on the US dollar, which can be linked to the rising US twin deficits, has led to rising reserve accumulation in US dollars, which constitutes a risk for macroeconomic stability. While the successive US interest rate increases since 2004 have put a hold on this trend, meanwhile the interest rate peak seems to be reached. Expectations about a new decline of US interest rates and a further decline of the dollar may create an incentive to further diversify the risk of one-sided dollar pegs based on basket strategies.

In East Asia, the yen and the euro may enter the currency baskets for (partially) different reasons. As Japan is a more important trading partner than the euro area and an important competitor in third markets, the yen may enter the currency basket to equilibrate intra-East Asian competitiveness. In contrast, trade matters less for the euro area, but the role of the euro as a macroeconomic anchor and international store of value is growing. While our estimations did not find robust evidence in favor of a (growing) role of the euro as an anchor currency in the region the role of the euro as a reserve currency in East Asia may be increasing. 


\section{References:}

Chinn, Menzie / Frankel, Jeffrey 2005: Will the Euro Eventually Surpass the Dollar as Leading International Reserve Currency? NBER Working Paper 11510.

Chmelarova, Viera / Schnabl, Gunther 2006: Exchange Rate Management in Developed and Underdeveloped Capital Markets. European Central Bank Working Paper 636.

Crockett, Andrew / Goldstein, Morris 1976: Inflation under Fixed and Flexible Exchange Rates. IMF Staff Papers 23, 509-544.

De Grauwe, Paul / Schnabl, Gunther 2005: Nominal versus Real Convergence with Respect to EMU Accession - EMU Entry Scenarios for the New Member States. Kyklos 58 (2005), 4, 481-499.

De Grauwe, Paul / Schnabl, Gunther 2007: Exchange Rate Stability, Inflation and Growth in the (South) Eastern and Central Europe. Forthcoming in Review of Development Economics.

Dooley, Michael / Folkerts-Landau, David / Garber, Peter 2004: The Revived Bretton Woods System: The Effects of Periphery Intervention and Reserve Management on Interest Rates and Exchange Rates in Center Countries. NBER Working Paper 10332.

European Central Bank ECB 2005: Review of the International Role of the Euro. Frankfurt December 2005.

European Commission 1990: One Market, One Money: An Evaluation of the Potential Benefits and Costs of Forming an Economic and Monetary Union, European Economy 44.

Eichengreen, Barry / Hausmann, Ricardo 1999: Exchange Rates and Financial Fragility. NBER Working Paper 7418.

Eichengreen, Barry 2005: Sterling's Past, Dollar's Future: Historical Perspectives on Reserve Currency Competition. NBER Working Paper 11336.

Fischer, Stanley 2001: Exchange Rate Regimes: Is the Bipolar View Correct? Journal of Economic Perspectives 15, 3-24.

Frankel, Jeffrey / Wei, Shang-Jin 1994: Yen Bloc or Dollar Bloc? Exchange Rate Policies in East Asian Economies. In Ito, Takatoshi / Krueger, Anne (eds.): Macroeconomic Linkages: Savings, Exchange Rates, and Capital Flows, Chicago, 295-329.

Galati, Gabriele / Wooldrige, Philip 2006: The Euro as a Reserve Currency: a Challenge to the Pre-Eminence of the US Dollar? BIS Working Paper 218.

Gudmundsson 2005: The Role of the Effective Exchange Rate in Monetary Frameworks: The International Experience. Mimeo.

Kawai, Masahiro 2002: Exchange Rate Arrangements in East Asia: Lessons from the 1997/98 Currency Crisis. Monetary and Economic Studies 20, 167-204.

Kawai, Masahiro 2006: Toward a Regional Exchange-Rate Regime in East Asia. Mimeo.

Lim, Ewe-Ghee 2006: The Euro’s Challenge to the Dollar: Different Views from Economists and Evidence from COFER and Other Data. IMF Working Paper 06/153.

McKinnon, Ronald 1963: Optimum Currency Areas. American Economic Review 53, 717-25.

McKinnon, Ronald 2005: Exchange Rates under the East Asian Dollar Standard: Living with Conflicted Virtue. MIT Press, Cambridge, Massachusetts.

McKinnon, Ronald / Ohno, Kenichi 1997: Dollar and Yen: Resolving Economic Conflict between the United States and Japan. MIT Press, Cambridge, Massachusetts.

McKinnon Ronald / Schnabl, Gunther 2003: Synchronized Business Cycles in East Asia and Fluctuations in the Yen/Dollar Exchange Rate. The World Economy 26, 8, 1067-1088.

McKinnon, Ronald / Schnabl, Gunther 2004a: The East Asian Dollar Standard, Fear of Floating, and Original Sin. Review of Development Economics 8, 3, 331-360.

McKinnon, Ronald / Schnabl, Gunther 2004b: A Return to Exchange Rate Stability in East Asia? Mitigating Conflicted Virtue. International Finance 7, 2, 169-201. 
Ogawa, Eiji / Ito, Takatoshi 2002: On the Desirability of a Regional Basket Currency Arrangement. Journal of Japanese and International Economies 16, 317-334.

Schnabl, Gunther 2005: The Russian Currency Basket. The Rising Role of the Euro for Russia's Exchange Rate Policies. Intereconomics 41, 3, 135-141.

Williamson, John 2000: Exchange Rate Regimes for Emerging Markets: Reviving the Intermediate Option, Washington D.C., Institute for International Economics.

Williamson, John 2005: A Currency Basket for East Asia, Not Just for China. Institute for International Economics: Policy Briefs in International Economics 05-1. 


\section{CESifo Working Paper Series}

(for full list see www.cesifo-group.de)

1812 Robert S. Chirinko and Hisham Foad, Noise vs. News in Equity Returns, September 2006

1813 Oliver Huelsewig, Eric Mayer and Timo Wollmershaeuser, Bank Behavior and the Cost Channel of Monetary Transmission, September 2006

1814 Michael S. Michael, Are Migration Policies that Induce Skilled (Unskilled) Migration Beneficial (Harmful) for the Host Country?, September 2006

1815 Eytan Sheshinski, Optimum Commodity Taxation in Pooling Equilibria, October 2006

1816 Gottfried Haber and Reinhard Neck, Sustainability of Austrian Public Debt: A Political Economy Perspective, October 2006

1817 Thiess Buettner, Michael Overesch, Ulrich Schreiber and Georg Wamser, The Impact of Thin-Capitalization Rules on Multinationals' Financing and Investment Decisions, October 2006

1818 Eric O’N. Fisher and Sharon L. May, Relativity in Trade Theory: Towards a Solution to the Mystery of Missing Trade, October 2006

1819 Junichi Minagawa and Thorsten Upmann, Labor Supply and the Demand for Child Care: An Intertemporal Approach, October 2006

1820 Jan K. Brueckner and Raquel Girvin, Airport Noise Regulation, Airline Service Quality, and Social Welfare, October 2006

1821 Sijbren Cnossen, Alcohol Taxation and Regulation in the European Union, October 2006

1822 Frederick van der Ploeg, Sustainable Social Spending in a Greying Economy with Stagnant Public Services: Baumol’s Cost Disease Revisited, October 2006

1823 Steven Brakman, Harry Garretsen and Charles van Marrewijk, Cross-Border Mergers \& Acquisitions: The Facts as a Guide for International Economics, October 2006

1824 J. Atsu Amegashie, A Psychological Game with Interdependent Preference Types, October 2006

1825 Kurt R. Brekke, Ingrid Koenigbauer and Odd Rune Straume, Reference Pricing of Pharmaceuticals, October 2006

1826 Sean Holly, M. Hashem Pesaran and Takashi Yamagata, A Spatio-Temporal Model of House Prices in the US, October 2006 
1827 Margarita Katsimi and Thomas Moutos, Inequality and the US Import Demand Function, October 2006

1828 Eytan Sheshinski, Longevity and Aggregate Savings, October 2006

1829 Momi Dahan and Udi Nisan, Low Take-up Rates: The Role of Information, October 2006

1830 Dieter Urban, Multilateral Investment Agreement in a Political Equilibrium, October 2006

1831 Jan Bouckaert and Hans Degryse, Opt In Versus Opt Out: A Free-Entry Analysis of Privacy Policies, October 2006

1832 Wolfram F. Richter, Taxing Human Capital Efficiently: The Double Dividend of Taxing Non-qualified Labour more Heavily than Qualified Labour, October 2006

1833 Alberto Chong and Mark Gradstein, Who's Afraid of Foreign Aid? The Donors' Perspective, October 2006

1834 Dirk Schindler, Optimal Income Taxation with a Risky Asset - The Triple Income Tax, October 2006

1835 Andy Snell and Jonathan P. Thomas, Labour Contracts, Equal Treatment and WageUnemployment Dynamics, October 2006

1836 Peter Backé and Cezary Wójcik, Catching-up and Credit Booms in Central and Eastern European EU Member States and Acceding Countries: An Interpretation within the New Neoclassical Synthesis Framework, October 2006

1837 Lars P. Feld, Justina A.V. Fischer and Gebhard Kirchgaessner, The Effect of Direct Democracy on Income Redistribution: Evidence for Switzerland, October 2006

1838 Michael Rauscher, Voluntary Emission Reductions, Social Rewards, and Environmental Policy, November 2006

1839 Vincent Vicard, Trade, Conflicts, and Political Integration: the Regional Interplays, November 2006

1840 Erkki Koskela and Mikko Puhakka, Stability and Dynamics in an Overlapping Generations Economy under Flexible Wage Negotiation and Capital Accumulation, November 2006

1841 Thiess Buettner, Michael Overesch, Ulrich Schreiber and Georg Wamser, Taxation and Capital Structure Choice - Evidence from a Panel of German Multinationals, November 2006

1842 Guglielmo Maria Caporale and Alexandros Kontonikas, The Euro and Inflation Uncertainty in the European Monetary Union, November 2006 
1843 Jan K. Brueckner and Ann G. Largey, Social Interaction and Urban Sprawl, November 2006

1844 Eytan Sheshinski, Differentiated Annuities in a Pooling Equilibrium, November 2006

1845 Marc Suhrcke and Dieter Urban, Are Cardiovascular Diseases Bad for Economic Growth?, November 2006

1846 Sam Bucovetsky and Andreas Haufler, Preferential Tax Regimes with Asymmetric Countries, November 2006

1847 Luca Anderlini, Leonardo Felli and Andrew Postlewaite, Should Courts always Enforce what Contracting Parties Write?, November 2006

1848 Katharina Sailer, Searching the eBay Marketplace, November 2006

1849 Paul De Grauwe and Pablo Rovira Kaltwasser, A Behavioral Finance Model of the Exchange Rate with Many Forecasting Rules, November 2006

1850 Doina Maria Radulescu and Michael Stimmelmayr, ACE vs. CBIT: Which is Better for Investment and Welfare?, November 2006

1851 Guglielmo Maria Caporale and Mario Cerrato, Black Market and Official Exchange Rates: Long-Run Equilibrium and Short-Run Dynamics, November 2006

1852 Luca Anderlini, Leonardo Felli and Andrew Postlewaite, Active Courts and Menu Contracts, November 2006

1853 Andreas Haufler, Alexander Klemm and Guttorm Schjelderup, Economic Integration and Redistributive Taxation: A Simple Model with Ambiguous Results, November 2006

1854 S. Brock Blomberg, Thomas DeLeire and Gregory D. Hess, The (After) Life-Cycle Theory of Religious Contributions, November 2006

1855 Albert Solé-Ollé and Pilar Sorribas-Navarro, The Effects of Partisan Alignment on the Allocation of Intergovernmental Transfers. Differences-in-Differences Estimates for Spain, November 2006

1856 Biswa N. Bhattacharyay, Understanding the Latest Wave and Future Shape of Regional Trade and Cooperation Agreements in Asia, November 2006

1857 Matz Dahlberg, Eva Mörk, Jørn Rattsø and Hanna Ågren, Using a Discontinuous Grant to Identify the Effect of Grants on Local Taxes and Spending, November 2006

1858 Ernesto Crivelli and Klaas Staal, Size and Soft Budget Constraints, November 2006

1859 Jens Brøchner, Jesper Jensen, Patrik Svensson and Peter Birch Sørensen, The Dilemmas of Tax Coordination in the Enlarged European Union, November 2006 
1860 Marcel Gérard, Reforming the Taxation of Multijurisdictional Enterprises in Europe, "Coopetition" in a Bottom-up Federation, November 2006

1861 Frank Blasch and Alfons J. Weichenrieder, When Taxation Changes the Course of the Year - Fiscal Year Adjustments and the German Tax Reform 2000/2001, November 2006

1862 Hans Jarle Kind, Tore Nilssen and Lars Sørgard, Competition for Viewers and Advertisers in a TV Oligopoly, November 2006

1863 Bart Cockx, Stéphane Robin and Christian Goebel, Income Support Policies for PartTime Workers: A Stepping-Stone to Regular Jobs? An Application to Young LongTerm Unemployed Women in Belgium, December 2006

1864 Sascha O. Becker and Marc-Andreas Muendler, The Effect of FDI on Job Separation, December 2006

1865 Christos Kotsogiannis and Robert Schwager, Fiscal Equalization and Yardstick Competition, December 2006

1866 Mikael Carlsson, Stefan Eriksson and Nils Gottfries, Testing Theories of Job Creation: Does Supply Create Its Own Demand?, December 2006

1867 Jacques H. Drèze, Charles Figuières and Jean Hindriks, Voluntary Matching Grants Can Forestall Social Dumping, December 2006

1868 Thomas Eichner and Marco Runkel, Corporate Income Taxation of Multinationals and Unemployment, December 2006

1869 Balázs Égert, Central Bank Interventions, Communication and Interest Rate Policy in Emerging European Economies, December 2006

1870 John Geweke, Joel Horowitz and M. Hashem Pesaran, Econometrics: A Bird's Eye View, December 2006

1871 Hans Jarle Kind, Marko Koethenbuerger and Guttorm Schjelderup, Taxation in TwoSided Markets, December 2006

1872 Hans Gersbach and Bernhard Pachl, Cake Division by Majority Decision, December 2006

1873 Gunther Schnabl, The Evolution of the East Asian Currency Baskets - Still Undisclosed and Changing, December 2006 